\title{
A modernidade em volta da fogueira no romance Mãe, materno mar, de Boaventura Cardoso
}

\author{
Sueli Saraiva* \\ Universidade de São Paulo
}

m 2001, ano em que recebeu o Prêmio Nacional de Cultura e Arte de Angola, o escritor Boaventura Cardoso publicou pela editora portuguesa Campo das Letras o seu terceiro romance - Mãe, materno mar -, inédito no Brasil. Sua obra em prosa, reconhecida internacionalmente e traduzida em diversas línguas, reúne ainda os contos Dizanga Dia Muenhu (1977 - editado no Brasil em 1982), O Fogo da Fala (1980) e A Morte do Velho Kipacaça (1997); e os romances O signo do fogo (1992) e Maio, mês de Maria (1997).

Boaventura Cardoso nasceu em 1944, em Luanda, e no final da década de 60 iniciou sua carreira literária com a publicação de contos e poemas nos jornais da cidade; no mesmo período, ingressou no serviço público. Membro-fundador da União dos Escritores Angolanos, ele jamais renunciou à literatura ao longo de sua vida profissional, sempre voltada à cultura e à arte. Foi dirigente do Instituto Nacional do Livro e do Disco (Inald), secretário de estado da Cultura e embaixador de Angola na França (1992-1999) e na Itália (2000-2002). Desde 2002 exerce o cargo de ministro da Cultura de Angola.

Mãe, materno mar (MMM) é a história de uma viagem de trem entre Malange, interior de Angola, e Luanda, a capital litorânea. Um percurso que normalmente levaria algumas horas acaba se prolongando por quinze anos para se chegar ao destino! E, aqui, o velho clichê do país que perdeu o trem (ou o bonde, ou jato, conforme a formulação preferida) da história ganha proporções originais e épicas. A viagem vai sendo interrompida por constantes avarias na locomotiva ou na via férrea, que forçam o veículo a ficar parado por longos períodos em diversas localidades, incluindo um trecho de mata, sem que os passageiros

\footnotetext{
Mestranda em Estudo Comparados de Literaturas de Língua Portuguesa na Universidade de São Paulo.
} 
possam optar por abandonar o inviável meio de transporte. Os motivos dessa impossibilidade, antes de nos remeterem simplesmente a $O$ anjo exterminador, de Buñuel, incluem riscos concretos: de um lado as estradas minadas, sitiadas pela guerra civil, e de outro, o temor das matas desconhecidas. É nesse entrelugar impregnado de incertezas quanto ao andamento de uma viagem finissecular que o trem, metáfora do espaço-nação angolano, abriga passageiros de diferentes extratos sociais, interesses e costumes, num palco de desavenças e conciliações, vida e morte, tradições e modernos modos de vida.

Por exemplo, logo na primeira parada imprevista, explode uma sangrenta (e hilariante) briga entre passageiros da segunda classe e operários da ferrovia embriagados, que se espalha por todas as classes. O saldo do confronto: dois operários da ferrovia e dois passageiros mortos. Mal os ânimos são apaziguados, surge uma nova confusão, agora entre os religiosos evangélicos de denominações concorrentes, por causa da forma como se dariam os funerais dos quatro mortos. $\mathrm{Na}$ busca de uma solução, os passageiros da primeira classe, a chamada moderna burguesia a bordo, são contundentes: para eles não há razão nenhuma para aquela discussão toda; a solução era enterrar os mortos como mandava a costumada tradição: "Apesar de temporariamente empoleirado no ramo do embondeiro, o pássaro esquece que o ninho dele está no arbusto?”. E Manecas, jovem passageiro que busca em Luanda um emprego na moderna economia angolana, "também não estava perceber porquê se estava perder tanto tempo [...] que ele nunca tinha entendido nem se preocupado com as populares tradições. Para quê? Valia a pena num mundo assim cada vez mais modernizado?" (MMM, p. 52).

Assim, a viagem vai-se pintando com as cores vivas da alegoria de uma sociedade que se faz por contrastes sociais, culturais e religiosos: são os novos-ricos tentando fazer a locomotiva funcionar pela força do dinheiro (o abastado pai da noiva que vinha com toda a família para o casamento na cidade seguinte), mas que não abdicam das tradições quando estas lhes são convenientes; são os jovens recém-escolarizados sonhando com uma vida na economia capitalista, como é o caso de Manecas; os líderes cristãos, ávidos por manter o poder sobre a massa de fiéis e obter os conseqüentes lucros, não dispensando também as sagradas forças tradicionais quando necessário: "E então os líderes religiosos se reuniram para perscrutar as vozes da Terra, esses secretos ares da natureza" (MMM, p. 76). 
É no paroxismo da pluralidade religiosa que se destaca a impávida figura do velho Ti-Lucas, o cego adivinho, guardião das tradições culturais e espécie de um Tirésias em terras africanas. Personagem sem lugar fixo, ele circula por todas as classes e interage com todos os passageiros indistintamente, cantando e aconselhando, trazendo a luz das sabedorias tradicionais para as mais complicadas situações.

No fundo, Boaventura Cardoso lança mão de todos esses recursos para fazer também uma vívida representação do conflito de interesses que envolvem as autênticas tradições culturais de seu país em contraposição aos apelos do capitalismo moderno. A religiosidade aparece como uma peça-chave desse jogo, uma metonímia que dá ao livro uma força de revelação insuspeitada, tornando-o veículo para uma realização literária de grande originalidade. Entre os vários recursos literários que dão contorno à narrativa, a oralidade tem papel predominante, graças ao primoroso trabalho de recriação lingüística com o uso de repetições, interjeições, além do constante deslocamento do foco narrativo, entre outros fascinantes achados.

No entanto, a estrutura do romance, também com base na chave religiosa, guarda segredos. Para dar conta desse imenso painel social, do mosaico de eventos e situações extravagantes, Boaventura divide o romance em três partes: "A terra", "O fogo" e "A água". A primeira tem em Manecas, o jovem em busca de emprego em Luanda, e na noiva burguesa indo para seu casamento "modernamente" preparado, os símbolos de uma geração que ao fazer o rito de passagem vê seus sonhos se desvanecerem pela impossibilidade de chegada ao seu destino com a rapidez que a juventude anseia. Assim também a jovem pátria angolana, em seu rito de passagem para o século XXI, conta com a velocidade de uma locomotiva para chegar ao seu moderno destino. Mas "A Terra", sobre a qual repousam os trilhos da locomotiva, vai ensinando que "é preciso saber estar no tempo de outro tempo" (MMM, p. 208).

A segunda parte da viagem dura oito anos, num terreno de mata entre Canhoca e Luinha, mais um não-lugar de descobertas e revelações. Agora o elemento tematizado é o fogo (que reacende as chamas de uma humanidade em conflito), em seus variados signos ígneos (na religiosidade, na sexualidade, etc.), tudo alimentado na grande fogueira acesa por Ti-Lucas. É em torno dessa fogueira que se reúnem líderes religiosos cristãos e seus fiéis, entoando canções ao deus africano do fogo. Também ao som do batuque, em torno da 
fogueira, concretiza-se "estranho casamento" da noiva, filha da burguesia, com o deus do fogo. Ainda nesse período, Manecas tem um sonho que simboliza o seu conflito interior pelo pertencimento aos dois mundos igualmente seus: as raízes tradicionais recém-descobertas e a sonhada modernidade capitalista.

$\mathrm{Na}$ terceira parte, o elemento água simboliza o próprio curso da vida: "Para Manecas, e para quase todos os passageiros, aquela viagem era só o rio correndo as correntes águas" (MMM, p. 207). As crianças nascidas no início da viagem já estão crescidas, os adultos calculam os prejuízos ocasionados pela fatídica jornada, e quem se destaca é um dos evangélicos, Profeta Simon Ntangu António, que, desde que recuperou seus poderes à custa dos costumes tradicionais, passou a realizar grandes prodígios.

O romance termina em aberto, como o mar que Manecas finalmente encontra e, como não poderia ser diferente, não parece causar o impacto esperado pelo garoto que partiu de Malange, e chegou homem feito na moderna Luanda, amadurecido pelos ritos que o apresentaram à sua terra em toda a sua complexidade. Uma terra que vislumbra uma identidade que não recusa a modernidade, mas não abdica de transmitir seus valores culturais.

A "escrita em processo" de Boaventura Cardoso - conforme o subtítulo do mais completo livro sobre o autor e sua obra, organizado por Rita Chaves, Tania Macêdo e Inocência Mata (Boaventura Cardoso, a escrita em processo. São Paulo: Alameda, 2005) - se destaca, portanto, pelo compromisso com uma literatura imersa na angolanidade de suas gentes, uma prosa engajada na análise dos novos tempos moldados na chama da independência, em 1975, no fracasso do projeto socialista, nas guerras civis e no capitalismo moderno que irrompe no país arrastando consigo uma série de contradições e dúvidas, captadas pelas lentes desse escritor e refletidas em sua literatura num estilo próprio, polifônico, dialógico e ironicamente crítico. 